\title{
Daun Sirsak (Annona muricata) sebagai Pestisida Nabati pada Sistem Budidaya dalam Ember
}

\author{
Soursop (Annona muricata) Leaves as Botanical Pesticide in Bucket Cultivation Systems
}

\author{
${ }^{1 *}$ R. Arif Malik Ramadhan, ${ }^{2)}$ Efrin Firmansyah \\ ${ }^{1,2)}$ Program Studi Agroteknologi Pertanian Fakultas Pertanian \\ Universitas Perjuangan Tasikmalaya \\ Jl. PETA no. 177 Kota Tasikmalaya, Jawa Barat, Indonesia, 46115 \\ *email: am.ramadhan@unper.ac.id
}

DOI:

10.30595/jppm.v5i1.9632

Histori Artikel:

Diajukan:

$26 / 01 / 2021$

Diterima:

$10 / 01 / 2022$

Diterbitkan:

$18 / 02 / 2022$

\begin{abstract}
ABSTRAK
Keberadaan organisme penganggu tanaman (OPT) pada sistem budidaya dalam ember(budikdamber) dapat menurunkan kualitas dan kuantitas hasil panen sementara pengendalian menggunakan pestisida sintetik tidak dapat dilaksanakan karena alasan kompatibilitas. Pemanfaatan pestisida nabati ekstrak daun A. muricata dapat digunakan sebagai pengendali OPT pada sistem budikdamber. Program ini dilaksanakan di kelompok wanita tani (KWT) Mawar Bodas kota Tasikmalaya. Komoditas yang dibudidayakan merupakan tanaman kangkung dan ikan lele. Proses budidaya kangkung dilaksanakan sebanyak dua periode tanam. Pada periode tanam pertama, tidak diaplikasian pengendalian dan pada periode tanam kedua diaplikasikan pestisida nabati daun A. muricata dengan konsentrasi 3\%. Parameter yang diamati berupa intensitas serangan OPT, hasil panen tanaman kangkung, respons mortalitas pada ikan lele, serta pemahaman anggota KWT Mawar Bodas dalampembuatan dan pengaplikasian pestisida nabati. Pestisida nabati A. muricata dengan konsentrasi $3 \%$ yang diaplikasi dengan interval 3 hari sekali dapat menurunkan intensitas serangan OPT sebesar 58\% dan dapat meminimalisir kehilangan hasil pada tanaman kangkung hingga 8,05\% lebih tinggi dibandingkan tanpa pengaplikasian pestisida nabati. Pengaplikasian pestisida nabati ekstrak A. muricata $3 \%$ tidak bersifat toksik terhadap tanaman kangkung dan ikan lele pada sistem budikdamber. Sebanyak 93\% anggota KWT Mawar Bodas telah menguasai cara pembuatan pestisida nabati dan $86 \%$ anggota KWT Mawar Bodas dapat mengaplikasian pestisida nabati dengan benar. Pengabdian ini penting dilaksanakan agar masyarakat mengetahui cara pengendalian OPT ramah lingkungan.
\end{abstract}

Kata kunci: Budikdamber; Kangkung; Lele; Pestisida Nabati

\begin{abstract}
The presence of plant pests and diseases (OPT) in cultivation system in buckets (budikdamber) can reduce the quality and quantity of crop yields, while using synthetic pesticides cannot be implemented for compatibility reasons. Utilization of A. muricata leaf extract as botanical pesticide can be used for controling pests and diseases in budikdamber systems. This program is implemented in the female farmer group (KWT) of Mawar Bodas, Tasikmalaya city. The commodities cultivated are kale and catfish. The process of cultivating kale is carried out for two planting periods. In the first planting period, no botanical pesticide was applied and in the second planting period, control was applied using botanical pesticide A. muricata leaves with $3 \%$ concentration. The parameters observed were the intensity of the pest and diseases attack, the yield of kale crop, catfish mortality response, and the understanding of KWT Mawar Bodas members in the manufacture and application of botanical pesticides.
\end{abstract}




\section{R. Arif Malik Ramadhan, Efrin Firmansyah}

Daun Sirsak (Annona muricata) sebagai Pestisida Nabati pada Sistem Budidaya dalam Ember

Botanical pesticide A. muricata with a concentration of $3 \%$ applied at intervals of 3 days can reduce the intensity of pests and diseases attacks by $58 \%$ and able to minimize yield loss in kale plants by up to $8.05 \%$ higher compare to yield without the application of botanical pesticides. The application of $3 \%$ A. muricata extract vegetable pesticide is not toxic to kale and catfish in the budikdamber system. As many as 93\% of KWT Mawar Bodas members have mastered how to make botanical pesticides and 86\% of KWT Mawar Bodas members can apply vegetable pesticides correctly. This service is important so that people know how to control environmentally friendly pests and diseases.

Keywords: Budikdamber; Kale; Catfish; Botanical Pesticide

\section{PENDAHULUAN}

Kebutuhan pangan yang kian meningkat, ketersediaan lahan yang semakin berkurang, serta kondisi penyebaran wabah Covid-19 di Indonesia merupakan permasalahan penting yang harus kita hadapi hadapi bersama. Berbagai program intensifikasi lahan telah diupayakan pemerintah guna mengatasi permasalahan ketersediaan pangan di masa pandemi ini. Menurut Badan Pusat Statistik, jumlah penduduk kota Tasikmalaya pada tahun 2020 sebesar 663.986 jiwa dan diperkirakan akan terus meningkat (BPS, 2020) sehingga kebutuhan masyarakat akan bahan pangan di kota Tasikmalaya juga akan terus meningkat. Pemerintah telah mensosialisasikan sistem budidaya ikan dan sayuran dalam ember (budikdamber) sebagai bentuk intensifikasi lahan dalam pemenuhan kebutuhan pangan keluarga di masa pandemi. Sistem budikdamber belum diadopsi dan dilaporkan oleh masyarakat kota Tasikmalaya sehingga peran aktif pemerintah, akademisi, serta masyarakat menjadi kunci keberhasilan penerapan dan sosialisasi sistem budikdamber di Kota Tasikmalaya.

Dalam setiap proses budidaya terdapat berbagai faktor pembatas yang mengakibatkan hasil panen kurang optimal, termasuk pada sistem budikdamber. Keberadaan organisme penganggu tanaman (OPT) merupakan salah satu faktor pengghambat yang dapat menurunkan kualitas dan kuantitas hasil panen. Pengendalian OPT pada sistem budikdamber tidak dapat memanfaatkan pestisida sintetik karena tidak kompatibel dengan sistem budikdamber yang diterapkan. Penggunaan pestisida sintetik dapat mencemari air dalam ember pemeliharaan ikan serta dapat meninggalkan residu pada tanaman yang dibudidayakan. MenurutAndriyani (2006), penggunaan pesisida sintetik dapat menimbulkan berbagai dampak negatif seperti pencemaran air, tanah, udara, rusaknya keseimbangan ekosistem, serta timbulnya dampak buruk bagi kesehatan masyarakat. Salah satu usaha untuk meminimalisir dampak negatif penggunaan pestsida sintetik dapat dilakukan dengan cara memanfaatkan pestisida nabati yang ramah lingkungan (Ramadhan et al., 2018). Pemanfaatan pestisida nabati dapat dijadikan solusi pengendalian OPT yang mudah, murah, ramah lingkungan, serta besifat kompatibel dengan sistem budikdamber. Pestisida nabati memiliki keunggulan dapat mudah terurai di alam, tidak bersifat toksik bagi manusia dan hewan, termasuk ikan lele yang dibudidayakan dengan sistem budikdamber.

Indonesia memiliki aneka ragam tanaman yang telah diteliti dan dapat dimanfaatkan sebagai pestisida nabati (Haryono, 2011). Tanaman sirsak (Annona muricata) merupakan salah satu tanaman yang telah banyak dimanfaatkan sebagai pestisida nabati (Syakir, 2011). Tando, (2018) melaporkan bahwa terdapat senyawa metabolit sekunder dalam tanaman sirsak yang dapat dimanfaatkan sebagai pengendali hama dan penyakit pada tanaman budidaya. Tanaman A. muricata dilaporkan dapat dijadikan sebagai pestisida nabati untuk mengendalikan hama walang sangit (Amrullah \& Herdiati, 2020), larva ulat krop kubis (Arimbawa et al., 2017), larva ulat grayak (Yanuwiadi et al., 2013), kutu daun dan kutu kebul (Idrus \& Maros, 2016), serta penyakit antraknosa (Zulkipli et al., 2018)

Keberadaan tanaman A. muricata di Kota Tasikmalaya dapat dimanfaatkan sebagai komposisi utama pestisida nabati. Pemanfaatan tanaman sirsak yang terdapat di kota Tasikmalaya sejalan dengan visi misi Universitas Perjuangan untuk mengembangkan 
sumberdaya dan kearifan lokal di kota Tasikmalaya. Program pemberdayaan masyarakat desa binaan ini mengkaji mengenai pengaruh pengendalian OPT dengan memanfaatkan pestisida nabati daun sirsak untuk meminimalisir kehilangan hasil akibat serangan OPT pada sistem budikdamber serta meningkatkan pengetahuan anggota kelompok tani mengenai cara membuat dan mengaplikasikan pestisida nabati.

\section{METODE}

Program pemberdayaan masyarakat desa binaan (PMDB) ini dilaksanakan pada bulan Agustus hingga bulan Desember 2020. Kegiatan ini dilaksanakan di lahan milik kelompok wanita tani (KWT) Mawar Bodas, Kelurahan Kahuripan, Kecamatan Tawang, Kota Tasikmalaya, Provinsi Jawa Barat. Kegiatan yang dilaksanakan meliputi transfer teknologi, pembuatan instalasi budikdamber, pemeliharaan tanaman kangkung, pemeliharaan ikan lele, pembuatan dan pengaplikasian pestisida nabati daun sirsak, skoring dan pengamatan, panen, dan evaluasi keberhasilan program.

Pembuatan instalasi budikdamber menggunakan ember plastik dengan volume 80 liter air sebanyak 30 buah. Ember tersebut dilubangi di bagian atas dengan menggunakan bor listrik sebanyak 15 lubang berdiameter 5 $\mathrm{cm}$. Lubang tersebut diperuntukkan sebagai tempat menyimpan netpot. Netpot terbuat dari gelas plastik dengan diameter $5 \mathrm{~cm}$ dan tinggi $10 \mathrm{~cm}$ sebanyak 450 buah. Netpot dilubangi dengan menggunakan besi panas agar air dapat diserap oleh akar tanaman. Media tanam yang digunakan merupakan campuran cocopeat dan arang sekam dengan rasio 1:1. Benih kangkung yang digunakan sebanyak 1350 benih yang dibagi dalam 450 netpot sehingga setiap netpot terisi 3 buah benih kangkung. Ikan lele yang digunakan merupakan ikan lele jenis sangkuriang yang didapatkan dari kecamatan Bungursari, Kota Tasikmalaya. Dalam satu buah ember dipelihara 25 ekor lele jenis sangkuriang berukuran 9-12 cm dan 45 tanaman kangkung.

Pemeliharaan kangkung dilaksanakan dengan menggunakan dua jenis perlakuan.
Tanaman kangkung dipanen sebanyak dua kali pemanenan. Pada periode panen pertama, tanaman kangkung hanya ditanam dalam netpot tanpa menerapkan perlakuan pengendalian OPT. Pada 1 minggu sebelum pemanenan dilakukan skoring kerusakan akibat OPT pada tanaman kangkung. Setelah panen pertama, media tanam diganti dengan media tanam yang baru kemudian kembali menyemai untuk periode tanam kedua. Pada periode panen kedua, tanaman kangkung diberikan perlakuan berupa penyemprotan pestisida nabati mulai 1 minggu setelah tanam dengan interval penyemprotan selama 3 hari sekali. Pemeliharaan lele meliputi pemberian pakan dan penggantian air pada ember pemeliharaan. Ikan lele diberi pakan sebanyak 3 hari sekali dengan menggunakan pelet berukuran $3 \mathrm{~mm}$. Keadaan air dalam ember dipantau dengan interval 24 jam sekali. Proses penggantian air dilaksanakan setiap 2 minggu selama 3 bulan. Pemanenan lele dilaksanakan bersamaan dengan pemanenan kangkung pada periode tanam kedua.

Pestisida nabati yang digunakan merupakan pestisida nabati berbahan dasar daun sirsak yang dilarutkan dalam air dengan konsentrasi 3\%. Cara pembuatan pestisida nabati daun sirsak yaitu dengan menyiapkan 300 gram daun sirsak basah yang kemudian dipotong kecil. Hasil potongan daun sirsak tersebut kemudian ditambahkan $700 \mathrm{ml}$ air kemudian diblender hingga halus. Setelah halus ditambahkan detergen sebanyak 5 g kemudian disaring hingga didapatkan ekstrak daun sirsak pekat (Gambar 1). Pemberian detergen dimaksudkan sebagai pengemulsi untuk mengangkat senyawa-senyawa aktif dari daun sirsak yang bersifat non-polar atau tidak larut dalam air. Ekstrak sirsak pekat dapat langsung digunakan atau dapat disimpan dalam suhu ruang dengan batas maksimum penyimpanan selama 48 jam. 


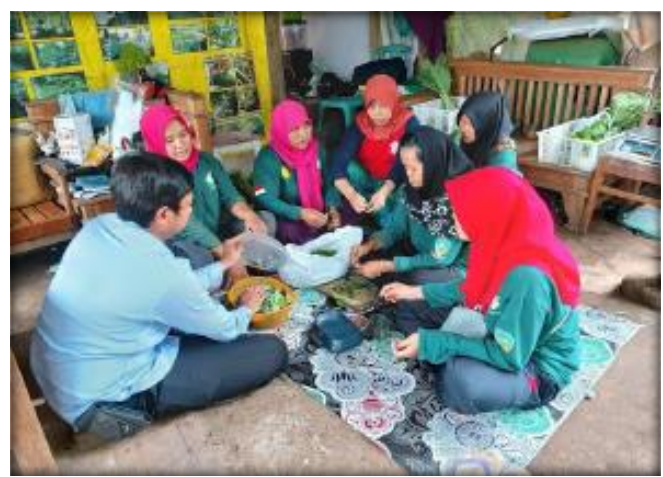

Gambar 1. Pembuatan pestsida nabati

Sebelum diaplikasikan, ekstrak daun sirsak pekat dikocok terlebih dahulu kemudian diencerkan kembali menggunakan air dengan perbandingan 1:9. Penyemprotan mulai dilakukan pada saat tanaman kangkung telah berusia 7 hari setelah tanam. Penyemprotan dilaksanakan pada pagi hari antara pukul 07.00 WIB hingga pukul 09.00 WIB dengan interval penyemprotan 3 hari sekali (Gambar 2).

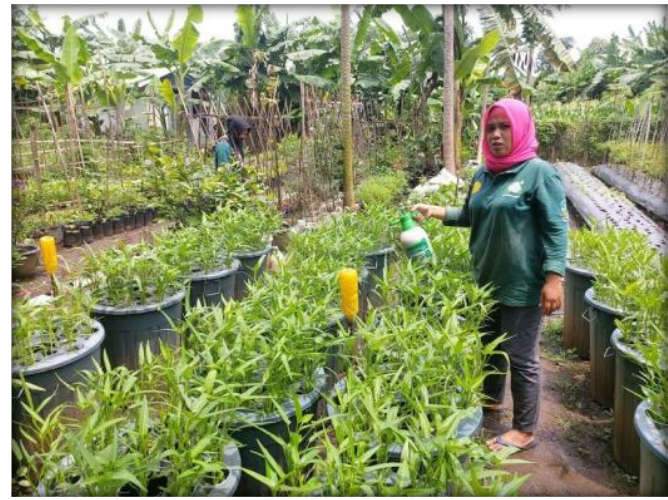

Gambar 2. Pengaplikasian pestisida nabati

Pengamatan OPT dilakukan pada 1 minggu sebelum panen dengan cara mengamati 30 netpot. Penghitungan intensitas kerusakan akibat OPT dilaksanakan dengan menggunakan metode skoring tingkat keparahan pada daun (daun terdefoliasi) menggunakan rumus dan kriteria intensitas serangan menurut Natawigena (1989) (Tabel 1).

$$
P=\frac{\Sigma(n \times z)}{N \times Z} \times 100 \%
$$

Keterangan

$\mathrm{P}:$ Intensitas serangan

$\mathrm{z}$ : Nilai skor

$\mathrm{n}$ : jumlah sampel yang mempunyai nilai skor yang sama
$\mathrm{N}$ : jumlah total sample yang diamati

$\mathrm{Z}$ : Nilai skor tertinggi

Tabel 1. Skor kriteria intensitas serangan menurut Natawigena (1989)

\begin{tabular}{c|cc}
\hline Skala & $\begin{array}{c}\text { Intensitas } \\
\text { kerusakan }\end{array}$ & Kategori \\
\hline 0 & 0 & Normal \\
1 & $1<\mathrm{X}<25$ & Ringan \\
2 & $25<\mathrm{X}<50$ & Sedang \\
3 & $50<\mathrm{X}<75$ & Berat \\
4 & $\mathrm{X}>75$ & Sangat Berat \\
\hline
\end{tabular}

Intensitas kerusakan pada tanaman kangkung periode panen pertama dan kedua dibandingkan berdasarkan hasil skoring. Parameter pengamatan penunjang berupa bobot tanaman kangkung yang dipanen pada periode panen kangkung pertama dan kedua serta mortalitas lele yang dibudidayakan bersamaan dengan tanaman kangkung dalam ember.

Selama pelaksanaan, diberikan transfer teknologi melalui penyampaian materi, pelatihan, dan advokasi terjadwal setiap minggu. Pengetahuan anggota KWT Mawar Bodas dievaluasi menggunakan kuisioner yang diberikan pada akhir pengabdian (setelah panen kangkung periode ke-2). Kuisioner yang dibagikan berisi beberapa poin pertanyaan untuk mengevaluasi pengetahuan anggota KWT Mawar Bodas terkait cara pembuatan dan pengaplikasian pestisida nabati.

\section{HASIL DAN PEMBAHASAN}

Hasil pengamatan intensitas serangan pada periode tanam pertama didapatkan 26 buah sampel terserang dengan kategori rendah dan 4 sampel terserang dengan kategori sedang. Rata-rata serangan pada periode tanam pertama sebesar $11,72 \%$. Pada periode tanam kedua diaplikasikan pestisida nabati daun sirsak sehingga intensitas serangan OPT menjadi menurun. Hasil pengamatan intensitas serangan pada periode tanam kedua didapatkan 30 sampel yang seluruhnya terserang dengan kategori rendah. Rata-rata serangan pada periode tanam kedua sebesar 4,92\%.. Berdasarkan data tersebut pestisida nabati daun sirsak 3\% yang diaplikasikan dapat menurunkan intensitasserangan OPT pada tanaman kangkung hingga 2,38 kali lebih rendah dibandingkan intensitas serangan pada 
tanaman kangkung yang tidak diberi perlakuan pestisida nabati (Gambar 3).

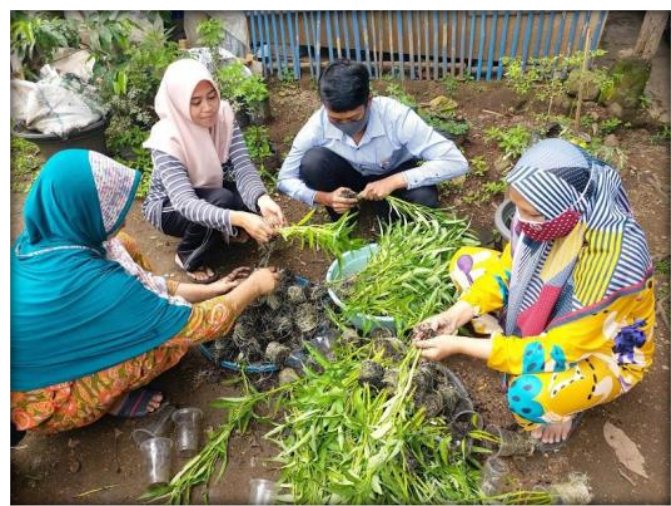

Gambar 3. Kegiatan panen kangkung

Intensitas kerusakan akibat serangan OPT dapat mempengaruhi hasil panen tanaman kangkung yang dibudidayakan. Hasil panen pada periode tanam pertama memiliki intensitas kerusakan sebesar $11,72 \%$ sedangkan pada periode tanam kedua memiliki intensitas kerusakan sebesar 4,92\%. Intensitas kerusakan pada hasil panen tanaman kangkung mempengaruhi kuantitas hasil panen. Bobot hasil panen pada periode tanam pertama sebesar 10,56 kg sedangkan pada periode tanam kedua didapatkan peningkatan bobot hasil panen menjadi $11,41 \mathrm{~kg}$ atau meningkat $8,05 \%$ dari bobot hasil panen periode pertama (Tabel 2).

Tabel 2. Hubungan intensitas serangan OPT terhadap hasil panen tanaman kangkung

\begin{tabular}{llll}
\hline & $\begin{array}{l}\text { Intensitas } \\
\text { Kerusakan } \\
\text { Kangkung }\end{array}$ & $\begin{array}{l}\text { Bobot } \\
\text { Kangkung }\end{array}$ & $\begin{array}{l}\text { Bobot } \\
\text { Ikan } \\
\text { Lele }\end{array}$ \\
\hline Panen 1 & $11,72 \%$ & $10,56 \mathrm{~kg}$ & - \\
Panen 2 & $4,92 \%$ & $11,41 \mathrm{~kg}$ & 127,9 \\
& & & $\mathrm{~kg}$ \\
\hline
\end{tabular}

Keterangan:

Panen 1= Tanpa pemberian pestisida nabati Panen 2 = Menggunakan pestisida nabati daun sirsak dengan interval penyemprotan 3 hari sekali.

Tidak terdapat gejala fitotoksisitas akibat pengaplikasian pestisida nabati $A$. muricata3\% terhadap tanaman kangkung yang dibudidayakan. Pengaplikasian pestisida nabati juga dinilai tidak berbahaya bagi ikan lele yang dibudidayakan dalam ember. Mortalitas ikan lele dihitung dari awal pemeliharaan hingga mencapai usia panen ( \pm 3 bulan) sebanyak 15 ekor atau setara dengan 2\% dari seluruh populasi ikan lele yang dibudiayakan (Gambar 4).

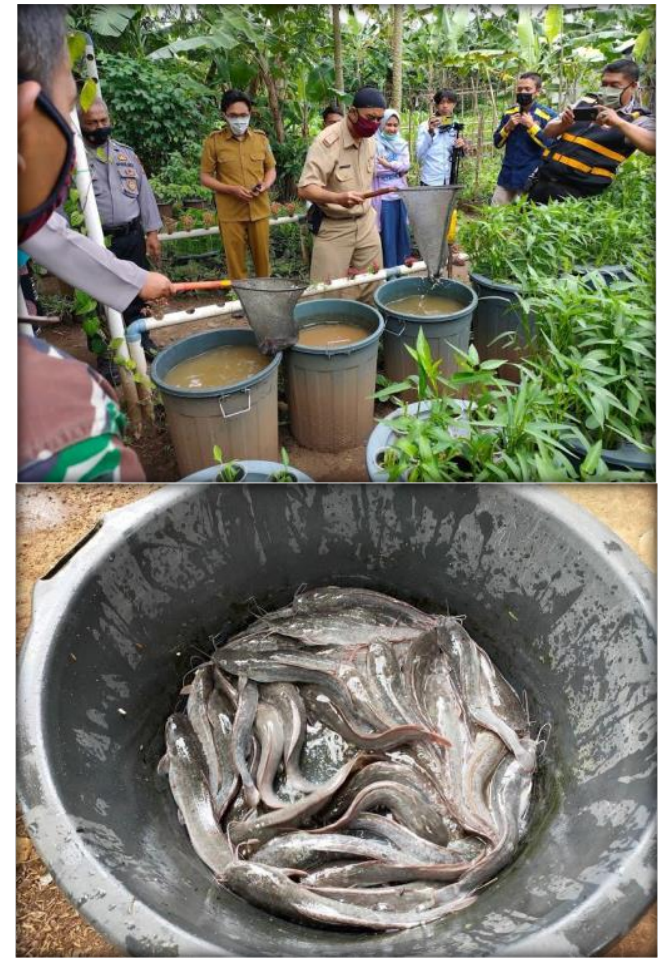

Gambar 4. Kegiatan panen kangkung periode tanam kedua dan panen ikan lele

Berdasarkan hasil evaluasi dengan menggunakan kuisoner menunjukkan hasil yang cukup baik. Proses evaluasi yang dihimpun melalui kuisioner menunjukkan data sebanyak 97\% anggota KWT Mawar Bodas telah mengetahui prosedur pembuatan pestisida nabati (Gambar 5a) dan $83 \%$ anggota KWT Mawar Bodas dapat mengaplikasikan pestsida nabati dengan tepat (Gambar 5b).

PEMBUATAN PESTISIDA NABAT

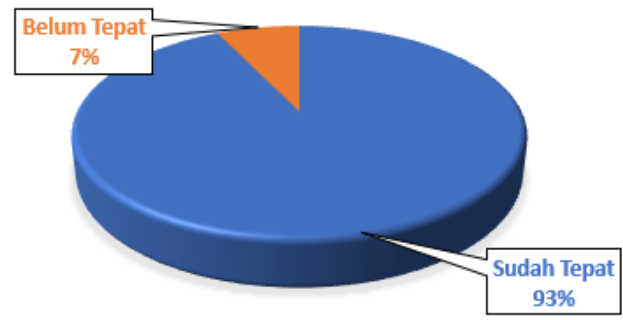

Gambar 5a. Evaluasi program pembuatan pestisida nabati. 
PENGAPLIKASIAN PESTISIDA NABATI

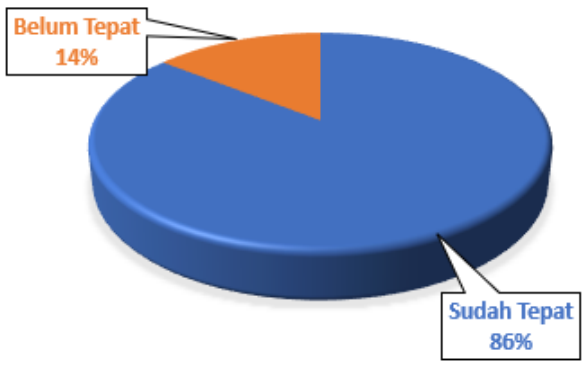

Gambar 5b. Evaluasi program pengaplikasian pestisida nabati.

\section{SIMPULAN}

Ekstrak A. muricata dengan konsentrasi 3\% dengan interval penyemprotan 3 hari sekali dapat meminimalisir intensitas serangan OPT pada sistem budikdamber kangkung-lele. Pengaplikasan pestisida nabati ekstrak A. muricata dapat menurunkan intensitas serangan OPT sebesar 58\%. Pengaplikasian pestisida nabati ekstrak $A$. muricata juga dapat meminimalisir kehilangan hasil padapanen kangkung hingga 8,05\% lebih tinggi dibandingkan tanpa pengaplikasian pestisida nabati. Pengaplikasian pestisida nabati ekstrak $A$. muricata $3 \%$ tidak bersifat toksik terhadap tanaman kangkung dan ikan lele yang dipelihara dalam sistem budikdamber. Tidak ada gejala fitotoksisitas pada tanaman kangkung dan tidak ada tanda-tanda toksisitas yang ditunjukkan oleh ikan lele. Mortalitas keseluruhan dari ikan lele yang dibudidayakan sebesar $2 \%$ dari keseluruhan populasi.

Hasil evaluasi keberhasilan program pemberdayaan masyarakat menggunakan kuisioner menunjukkan hasil yang baik. sebanyak 97\% anggota KWT Mawar Bodas telah mengetahui prosedur pembuatan pestisida nabati dan $83 \%$ anggota KWT Mawar Bodas dapat mengaplikasikan pestsida nabati dengan tepat.

\section{UCAPAN TERIMA KASIH}

Ucapan terima kasih disampaikan kepada Lembaga Penelitian dan Pengabdian Masyarakat kampus Universitas Perjuangan Tasikmalaya, yang telah memberikan dana program pengembangan masyarakat desa binaan ini. Ucapan terima kasih disampaikan kepada KWT Mawar Bodas kota Tasikmalaya sebagai kelompok yang bekerjasama dalam pelaksanaan program ini, serta kepada pemerintah daerah dan penyuluh pertanian lapangan yang telah memberikan izin kegiatan serta berpartisipasi aktif dalam setiap proses pelaksanaan program ini.

\section{DAFTAR PUSTAKA}

Amrullah, S. H., \& Herdiati. (2020). Efektivitas Ekstrak Biji dan Daun Sirsak untuk Pengendalian Hama Walang Sangit pada Tanaman Padi. 2(1), 26-32.

Andriyani, R. (2006). Efektivitas Ekstrak Daun Bintaro (Cerbera odollam) Sebagai Insektisida Ulat Penggerek Bunga Dan Polong (Maruca testulalis) Pada Tanaman Kacang Panjang (Vigna sinensis L.). 7, 95-106.

Arimbawa, D. M., Martiningsih, N. G. A. E., \& Javandira, C. (2017). 3) 123). Agrimeta, $8(15)$.

Haryono. (2011). Konsep dan strategi penelitian dan pengembangan pestisida nabati. Semnas Pestisida Nabati IV , 1-8.

Idrus, I., \& Maros, S. Y. (2016). Efektifitas Pestisida Nabati dalam Mengendalikan Hama pada Tanaman Cabai. 1(2), 129136.

Ramadhan, R. A. M., Widayani, N. S., Puspasari, L. T., Hidayat, Y., \& Dono, D. (2018). Laboratory Evaluation of Neem formulation bioactivity against Crocidolomia pavonana F. larvae. Cropsaver, 1(1), 37-41. https://doi.org/10.24198/cs.v1i1.20334

Syakir, M. (2011). Status Penelitian Pestisida nabati Pusat Penelitian dan Pengembangan Tanaman Perkebunan. Semnas Pestisida Nabati IV IV, 22, 10-12.

Tando, E. (2018). Review: Potensi Senyawa Metabolit Sekunder dalam Sirsak ( Annona Murricata ) dan Srikaya ( Annona squamosa ) sebagai Pestisida Nabati untuk Pengendalian Hama dan Penyakit pada Tanaman. Jurnal Biotropika, 6(1), 21-27. https://pdfs.semanticscholar.org/089b/3c 6cdcb8c476c6a55c4bd4c0db59d03ad142 
R. Arif Malik Ramadhan, Efrin Firmansyah

Daun Sirsak (Annona muricata) sebagai Pestisida Nabati pada Sistem Budidaya dalam Ember

.pdf

Yanuwiadi, B., Leksono, A. S., H, H. G., \& Fathoni, M. (2013). Potensi Ekstrak Daun Sirsak, Biji Sirsak dan Biji Mahoni untuk Pengendalian Ulat Grayak ( Spodoptera litura L .). 2(1), 88-89.
Zulkipli, S., Marsuni, Y., Rosa, H. O., Agroteknologi, P., Mangkurat, F. P. L., \& Selatan, B. (2018). Pada Tanaman Cabai Besar. 1(02), 32-34. 